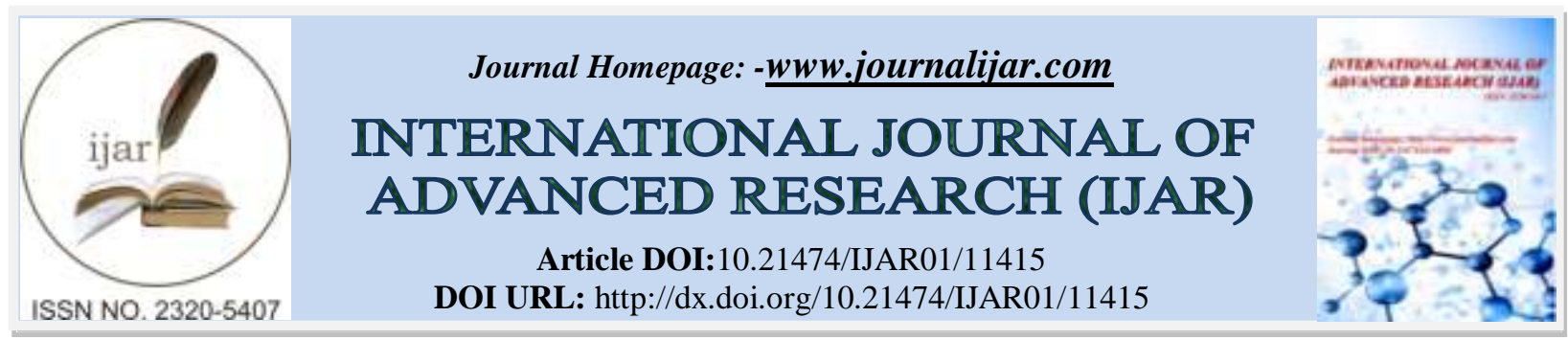

RESEARCH ARTICLE

\title{
EFFECT OF ELECTRONIC BANKING ON BANK PERFORMANCE: EVIDENCE FROM DJIBOUTI
}

\author{
Musah Ismaila, Shaibu Ali, Sherif Heiman Shaban, Yusif Ali and Ismail Awudu Yahyah \\ Research Fellows, Islamic Finance Research Institute of Ghana, H/No. GA-044-0559 Odoitso Street, Greater Accra, \\ Ghana.
}

\section{Manuscript Info}

Manuscript History

Received: 28 May 2020

Final Accepted: 30 June 2020

Published: July 2020

Key words:-

Electronic Banking, Bank Performance,

Customer Satisfaction, Djibouti

\section{Abstract}

The concept of electronic banking today has given birth to a number of modern technologies in the banking industry, and many banks across the world in recent times have improved their service delivery especially with the new technologies. This is contributing significantly to the performance of the banks. This study examines the effect of electronic banking on bank performance in Djibouti. A structured Likert scale was used for the data collection. 250 respondent were selected on convenient basis from different banks in Djibouti. Structural Equation Model (SEM) and partial least square were used for the Analysis. The results revealed that there is a significant positive relationship between electronic banking and bank performance. This study contributes theoretically to the electronic banking literature especially in the context of Africa. Contributions and recommendations have been suggested with regards to future research works in this field.

Copy Right, IJAR, 2020, All rights reserved.

\section{Introduction:-}

During the last decade, the introduction of electronic banking was a challenge to the people of Djibouti and its neighbouring countries. According to Polatoglu and Ekin (2001) they explained that majority of the banks at the time rejected electronic banking when it was introduced because they didn't see any benefit of using it. They further explained that, internet banking comes with huge cost which they think could be used to pay many tellers in the industry.

In recent years, technology has found its way into the banking industry of Djibouti and it is making significant changes in that sector. Most of the traditional banks sought to serve their customers in a traditional way but they pay attention to cost, which they consider as a main element in the banking sector. Singh and Malhotra (2007) defined Electronic banking as delivering banking services and product to customers over the electronic and communication network. Introduction of electronic banking services into the banking industry of Djibouti has rapidly improved ways of conducting businesses. Furthermore, customer satisfaction level has improved after the introduction of the services.

Daniel (1999) in his works explained that electronic banking is the delivery of services to customers by banks via different kinds of terminals or medium such as the mobile phones, personal computer digital television and telephones. Abid and Noreen (2006) further explained that electronic banking is the use of ICT and Electronic platforms to transact or interact with the stakeholders of the banks. Wallis (1997) explained that electronic banking creates a platform for transaction electronically without the use of physical cash. 
Customer satisfaction according to Hansemark and Albinsson (2004) is the difference of what customers anticipate and what they have received from the service provider. Oliver (1997) further explained that customer satisfaction is about the consumer's judgement of a product or a service whether the product or the service has fulfilled the need, goal or desire of the customer or not. Kotler (2000) again pointed out that satisfaction is about customer's anticipation or disappointment from services or products in relation to the customer's expectations. Long term relationship and maintenance of customers is based on their level of satisfaction, which is paramount to most institutions (Sweeney and Swait, 2008). Customer's satisfaction with a company can lead to company performance.

Previous literature has proven that customer satisfaction affects customer loyalty and customer loyalty affects the financial performance of the company (Hallowell, 1996). Chi and Gürsoy (2009) also explained that satisfied customers are the ones who turn into loyal customers and they will gradually buy more from the company which will eventually lead to high sales for the company and subsequently lead to high returns. These theories are being supported fully by many scholars like (Anderson and Fornell, 1994; Schneider and Bowen 1995; Heskett et al. 1994; Rust et al. 1995).

Even though many research works have been done around the area of electronic banking and bank performance, most of them concentrated on the context of developed countries neglecting the developing countries.This study seeks to address that gap by examining the effect of electronic banking on bank performance in the context of developing countries using Djibouti as a case study.

\section{Materials and Methods:-}

\section{Electronic Banking and its relationship with Customer Satisfaction:}

The introduction of electronic banking today has made the financial sector a competitive one and a profit-making venture. This has whetted the appetites of investors to invest more into the banking industry. The introduction of technological concepts, policies, techniques etc... to the banking industry has become a topic of importance and serious concern to all banks and its stakeholders. As a result, financial sector today has seen a rapid change by serving customers electronically.

According to Mishra and Kiranamai (2009) the world of E-banking started with the use ATM and it was piloted by Finland. Most E-banking services were commonly used in the developed countries. Claessens, Glaessner and Klingebiel (2000) explained that the developing countries especially those from Africa can tap into the experience of the developed countries for the implementation of the technology. Most banks in Djibouti today are implementing E-banking as a means of enhancing service quality in that sector. The introduction of E-banking services has increased the level of customer satisfaction in some banks in Djibouti.

A research work conducted by Kumbhar (2011) on customer satisfaction towards E-banking services in ICICI bank in India. Their empirical finding suggested that there is a significant positive relationship between electronic banking and customer satisfaction. The outcome of another work commissioned by Woldie, Hinson, Iddrisu and Boateng (2008) to study how internet banking could improve the relationship between customers (client) and banks in Ghana showed, among others, that there was a positive relationship between internet banking and customer satisfaction.

Furthermore, the works of Ahmad and Al-Zu'bi (2011) suggested that electronic banking and customer satisfaction and loyalty have a significant positive relationship. They sampled 179 customers from 24 commercial banks. Mobarek (2007) further looked at 100 customers from the four (4) main commercial banks in Botswana. The study's outcome revealed that there is a positive significant relationship between electronic banking and customer satisfaction.

Lastly, the works of Aghaei, Biglar, Jamshidian and Asadollah (2013) on 384 customers from the main commercial banks in Iran investigated the effect of electronic banking on customer satisfaction and found out that there is a positive relationship between the two variables. Based on the above empirical evidence, the following hypothesis is proposed;

H1: Electronic banking has a positive impact on Customer satisfaction. 


\section{Customer Satisfaction and its relationship with Bank Performance:}

A lot of banks are now using customer satisfaction as a strategic tool to gain competitive advantage over other banks in the banking industry. According to Munari et al. (2013) customer satisfaction is one of the criterion used to assess the relationship between the bank and its customer base. The higher the customer base the higher the profit and the lower the intention of the customer to switch to another bank. Customer satisfaction is an important driver when it comes to the success of a bank (Hoq and Amin, 2010).

Terpstra et al. (2014) explains customer satisfaction as satisfaction that a customer may derive from a product or a service. He further explained that customer satisfaction of a bank customer refers to the states of mind of a customer concerning the bank, his positive experience with the bank over a period of time. The traditional strategic marketing concept revealed that customer satisfaction technically influences financial performance of firms. The main ideology behind it is that the more the customer becomes satisfied the more they will demonstrate loyalty which subsequently leads to an increase in financial outcome of the company. Most banks consider customers as their assets and their satisfaction is primary goal of the bank (Dossi and Patelli, 2010).

Previous empirical studies have proven that, there is a positive association between customers and financial outcomes. The likes of Anderson, Fornell and their colleagues who developed an index for measuring customer satisfaction and performance (American Customer Satisfaction Index, 2001; Fornell, 1992; Fornell, Johnson, Anderson, Cha, and Everitt Bryant, 1996) have all attest to the fact that there is a positive relationship between customer satisfaction and performance. Yeung and Ennew (2000) in their studies which they focused on customer satisfaction and bank performance suggested that there is a positive relationship between the two variables. The only problem is that they use a cross-section data which has a problem of endogeneity. Mittal and Frennea (2010) had similar results when they link the effect of customer satisfaction on Bank performance.

Guo, Kumar and Jiraporn (2004) in their research works revealed that customer satisfaction has a greater influence on financial performance of a firm. The works of Kanning and Bergmann (2009) proves that there exist a positive relationship between customer satisfaction and bank performance. Based on the above empirical assertion, we propose the hypothesis below;

H2: customer satisfactionhas direct positive relation with bank performance.

\section{Relationship between Electronic Banking and Bank Performance:}

The advent of technology has changed almost all aspects of our lives. Among them is the introduction of electronic banking in the banking sector. This has led to a total redefinition of the way the banks operate (Sumra, Manzoor, Sumra and Abass, 2011). Today in the banking world, electronic banking is seen as a main driver to the success of a bank (Sumra et. al. 2011). This has pushed the investors of the banks to invest more in information technology to enhance banking processes. The availability of electronic banking system alone is expected to affect the bank's financial performance positively.

Based on industry analysis, the impact of electronic banking on banking industries has generated a notable interest on revenue generation and growth of banks (Berger, 2003). He explained that electronic banking eliminates all physical boundaries and all geographical issues of banking services. This alone increases customer base of banks which leads to higher sales and subsequently make higher profits. Previous scholars have done a lot of works around electronic banking and bank performance and they have confirmed the assertion that electronic banking influences bank performance positively. For instance, the works of Hasan, Maccario and Zazzara, (2002) on the topic "Do Internet Activities Add Value? The Italian Bank experience" They drew some samples from Italian banks to check whether internet banking contributes to the performance of the bank. The results revealed that internet banking institutions were performing better and significantly than the non-internet banking group.

Hernando and Nieto (2005) also carried out similar study on some banks in Spain, they found out that banks that adopt electronic banking channels perform better in terms of profitability than those who do not. Another investigation by Bello and Dogarawa (2005) on Nigerian banks examined the impact of electronic banking on customer satisfaction that can lead to bank performance. They found out that a lot of Nigerians were aware of electronic banking and they were satisfied with the service. The study further revealed that satisfied customers are willing to pay more for the electronic banking services, and this can lead to the bank making a lot of profit. 
In the works of Deyoung, Lang and Nolle (2006) they conducted a comparative analysis to look at the impact of internet banking on financial performance of the banks in their communities in the United States from the period of 1999 - 2001. The results of the study show that Adoption of internet banking has improved the community banks' profitability especially on their revenue from deposit services charge. The study finally revealed that internet adoption does contribute significantly to bank profitability. Another study by Oginni, Mohammed, El-Maude and Abam (2013) on the effect of electronic banking on bank performance from a Nigerian perspective found out that there is a positive significant relationship between electronic banking and bank performance. Similar to the works of Ongare (2013), he found out that there exist a positive relationship between electronic banking and bank performance. Based on the above discussions, we propose the following hypothesis:

H3: There is a positive relation between Electronic Banking and Bank performance

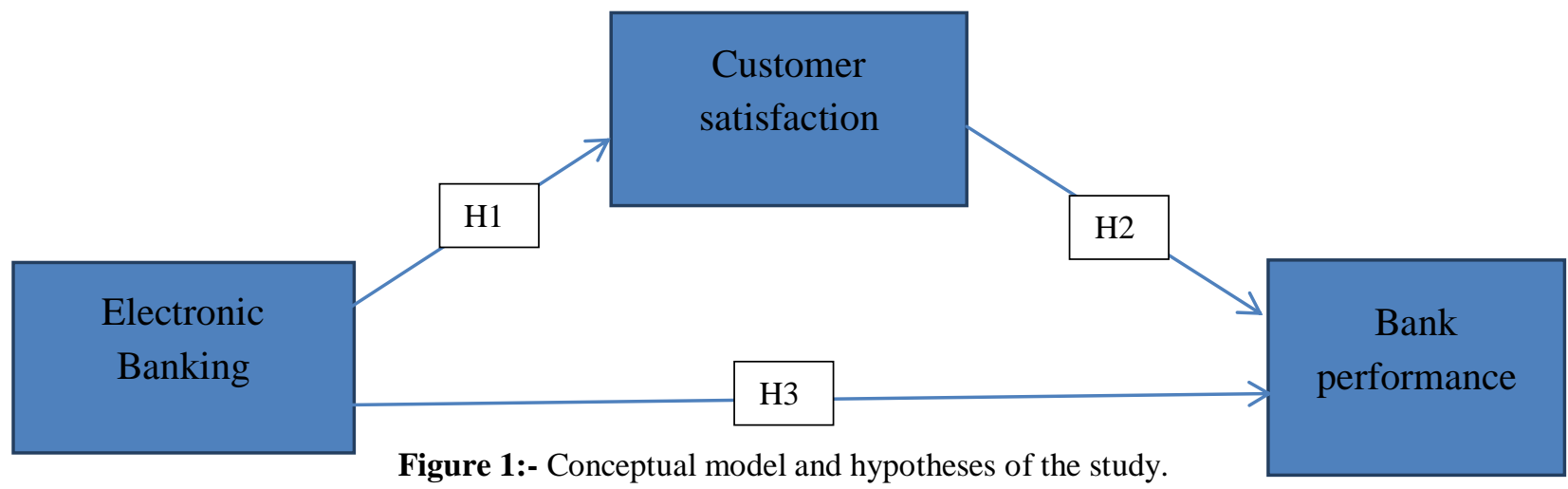

This paper employed the survey methodology which considered the use of quantitative techniques for collection and analyzing of data. Structured questionnaire was adopted to measure the quantitative variables. The objective of this study is to investigate the effect of Electronic Banking on Bank Performance with a mediating role of customer satisfaction.

Random sampling technique was employed to select the respondent from some selected banks in Djibouti. Four hundred (400) respondent were selected; but only two hundred and fifty (250) responses were received and considered after initial data cleaning. The study also adopted a Likert scale, ranging from $1=$ Strongly disagree to 5 = strongly agree and as well considered relevant questions from other researchers who used similar studies. The questionnaire was in three (3) different folds. The first fold contains questions on demographics, the second considered the measurement of construct whiles the third fold sought for the dependent variables.

Measurement of electronic banking was adopted from Han and Baek, (2004). Chiou and Droge (2006) was adopted for customer satisfaction while Hair Jr, Hult, Ringle, and Sarstedt (2016) was adopted for organizational performance measurement.

Data collected from respondents were analyzed through the help of SmartPLS3 and SPSS version 22. SPSS was considered for demographic Analysis while testing of hypothesis was done using Stata and SmartPLS3 for structural equation model. Confirmatory and Exploratory factor analysis were adopted for assessing and purifying the unidimensionality of items on the scale. And again assess discriminant validity among the constructs.

\section{Results:-}

The following demographics were extracted from the questionnaire; Age, Gender, Level of education and Types of banks.

Table 1:- Gender of respondents.

\begin{tabular}{|l|l|l|l|l|l|}
\hline \multicolumn{2}{|c|}{} & Frequency & Percent & Valid Percent & Cumulative Percent \\
\hline \multirow{2}{*}{ Valid } & Male & 174 & 69.6 & 69.6 & 69.6 \\
\cline { 2 - 6 } & Female & 76 & 30.4 & 30.4 & 100.0 \\
\hline
\end{tabular}




\begin{tabular}{|l|l|l|l|l|l|}
\hline & Total & 250 & 100.0 & 100.0 & \\
\hline
\end{tabular}

Results from the above table- 1 depict that 174 respondents were males representing $69.6 \%$, and 76 respondent representing $30.4 \%$ are females. This means that majority of the respondents are males.

Table 2:- Age of respondents.

\begin{tabular}{|l|l|l|l|l|l|}
\hline \multicolumn{2}{|c|}{} & Frequency & Percent & Valid Percent & Cumulative Percent \\
\hline \multirow{4}{*}{ Valid } & $18-125$ years & 38 & 15.2 & 15.2 & 15.2 \\
\cline { 2 - 6 } & $26-33$ years & 171 & 68.4 & 68.4 & 83.6 \\
\cline { 2 - 6 } & $34-41$ years & 37 & 14.8 & 14.8 & 98.4 \\
\cline { 2 - 6 } & 42 years and above & 4 & 1.6 & 1.6 & 100.0 \\
\cline { 2 - 6 } & Total & 250 & 100.0 & 100.0 & \\
\hline
\end{tabular}

The response from table - 2 above shows that 38 of the respondents representing $15.2 \%$ were between the ages of 18 25 years; 171 respondents representing $68.4 \%$ were between the ages of $26-33$ years; 37 respondents representing $14.8 \%$ were between the ages of $34-41$ years; 4 respondents representing $1.6 \%$ were above the age of 42 years. This means that majority of the respondents are between the ages of 26-33years.

Table 3:- Educational level of respondents.

\begin{tabular}{|l|l|l|l|l|l|}
\hline \multicolumn{2}{|c|}{} & Frequency & Percent & Valid Percent & Cumulative Percent \\
\hline \multirow{3}{*}{ Valid } & Basic level & 3 & 1.2 & 1.2 & 1.2 \\
\cline { 2 - 6 } & High School & 1 & .4 & .4 & 1.6 \\
\cline { 2 - 6 } & Diploma & 7 & 2.8 & 2.8 & 4.4 \\
\cline { 2 - 6 } & Undergraduate & 39 & 15.6 & 15.6 & 20.0 \\
\cline { 2 - 6 } & Graduate & 188 & 75.2 & 75.2 & 95.2 \\
\cline { 2 - 6 } & Others & 12 & 4.8 & 4.8 & 100.0 \\
\cline { 2 - 6 } & Total & 250 & 100.0 & 100.0 & \\
\hline
\end{tabular}

The results in table -3 above shows that 3 of the respondent representing 1.2\% are from the Basic level; 1 respondent representing 0.4 is from the High school whiles 7 respondent representing 2.8\% are from diploma level; 39 of the respondent representing $15.6 \%$ are from the undergraduate level whiles 188 of the respondent representing $75.2 \%$ are from the graduate level; 12 of the respondent representing $4.8 \%$ are from other levels of education. This means that majority of the respondents are graduates.

Table 4:- Type of bank respondents operate.

\begin{tabular}{|l|l|l|l|l|l|}
\hline \multicolumn{9}{|c|}{} & Frequency & Percent & Valid Percent & Cumulative Percent \\
\hline \multirow{3}{*}{ Valid } & Public & 146 & 58.4 & 58.4 & 58.4 \\
\cline { 2 - 6 } & Private & 104 & 41.6 & 41.6 & 100.0 \\
\cline { 2 - 6 } & Total & 250 & 100.0 & 100.0 & \\
\hline
\end{tabular}

The results in table- 4 above shows that 146 of the respondents representing $58.4 \%$ are from the public bank whiles 104 of the respondents representing $41.6 \%$ are from the private bank. This means that majority of the respondent comes from the public bank.

\section{Measurement model reliability and validity:}

Construct reliability checks the consistency of internal variables and does evaluation of item loadings with an acceptable region of 0.70 and considered the Cronbach's alpha of 0.70 (J. Hair, Ringle, andSarstedt, 2011; Ringle, Wende, and Becker, 2015). Furthermore, the variables in Table-5 below shows that their Cronbach's alpha is above the acceptable region of the 0.70 .This can be easily explained that the variables are highly reliable.Construct validity assesses the level to which a measures symbolise and are associated with observed eventualities of the construct through the principal theory (Fornell and Larcker, 1981a; Fornell and Larcker, 1981b). The evaluations were done through convergent and discriminant validity (Ringle et al., 2015) Composite reliability (CR) and 
average variance extracted (AVEs) have satisfied the minimum of 0.70 and 0.50 respectively (Fornell \& Larcker, 1981b; Ringle et al., 2015).

The variables in Table-5 shows that their Cronbach's alpha is above the acceptable region of the 0.70.This can be easily explained that the variables are highly reliable.

Table 5:- Item Loadings \& Construct Reliability.

\begin{tabular}{llllll}
\hline ITEMS & FL & CA & rho_A & CR & AVE \\
\hline CSAT1 & 0.816 & 0.936 & 0.937 & 0.950 & 0.759 \\
CSAT2 & 0.847 & & & & \\
CSAT3 & 0.922 & & & & \\
CSAT4 & 0.861 & & & \\
CSAT5 & 0.895 & & & \\
CSAT6 & 0.883 & & & 0.942 & 0.763 \\
EB1 & 0.834 & 0.922 & 0.924 & & \\
EB2 & 0.854 & & & & \\
EB3 & 0.921 & & & & \\
EB4 & 0.861 & & & & \\
EB5 & 0.896 & & & & \\
BP1 & 0.772 & 0.829 & 1.053 & \\
BP2 & 0.946 & & & \\
BP3 & 0.847 & & & \\
\hline
\end{tabular}

Notes: CSAT- Customer Satisfaction, EB - Electronic Banking, BP - Bank Performance , FL -Item Loadings , CA - Cronbach's Alpha, CR- Composite Reliability, AVE -Average Variance Extracted.

Discriminant Analysis is a statistical tool that correlate constructs that are higher than any other construct on its scale (Messick, 1988) ${ }^{[36] .}$

Table 6:- Discriminant Validity.

\begin{tabular}{|l|l|l|l|}
\hline & BP & CSAT & EB \\
\hline BP & $\mathbf{0 . 8 5 8}$ & & \\
\hline CSAT & $\mathbf{0 . 0 7 2}$ & $\mathbf{0 . 8 7 1}$ & \\
\hline EB & $\mathbf{0 . 0 5 5}$ & $\mathbf{0 . 7 9 5}$ & $\mathbf{0 . 8 7 4}$ \\
\hline
\end{tabular}

The Table-6 above clearly shows factors loaded are higher than any other factor on the scales. Bank performance (BP) on it scale recorded a value of 0.8 , customer satisfaction (CSAT) and electronic banking (EB) recorded a value of 0.8 which appears to be higher than the rest on the scale. 


\section{Empirical Findings:}

According to Ringle et al. (2015) the determination of the significance of t-value, p-value, t-statistics and regression

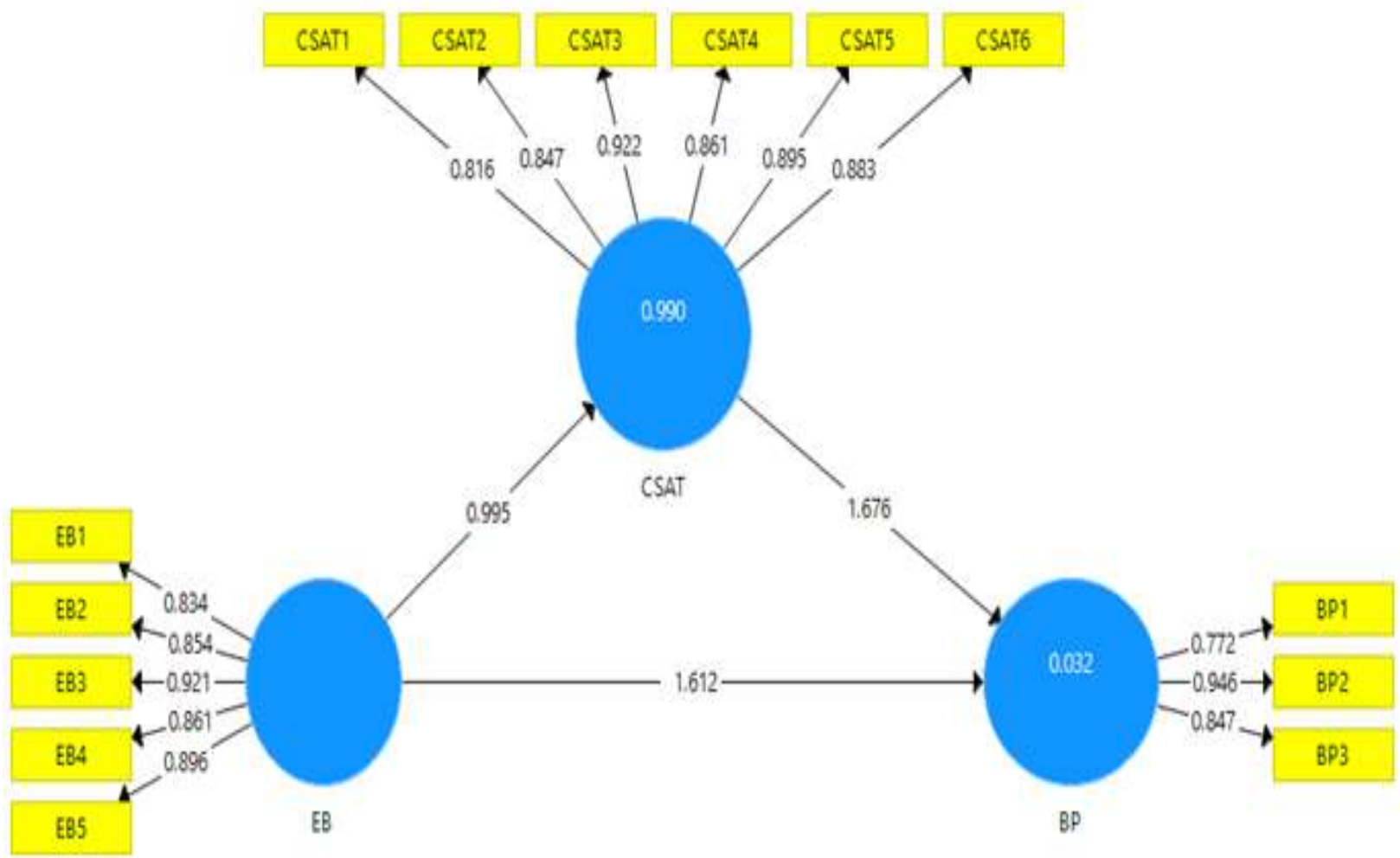

weights are done so as to simulate the model. The outcome of the model tested is presented in table-5 above.

\section{Hypothesis Analysis:}

Test of hypothesis was carried out on the effect of E-banking on bank performance using the statistical tool SmartPLS V.3 software. The results of the tested variables showed a significant and positive relationship with the predictor variables. Taking the first model, a test was carried out on the effect of E-banking on customer satisfaction. EB $(\beta=0.300 ; t=13.76, p<0.000)$ and this led to the acceptance of hypothesis $(\mathrm{H} 1)$. This suggest that E-banking has significant great effect on customer satisfaction. Furthermore, the beta in the results shows that when E-banking increases by $1 \%$ customer satisfaction increases by $30 \%$. Thus, the more the bank introduces better E-banking services the more the customers will patronize the services of the bank. This findings supports the earlier findings of Aladawani (2001).

Table 6:- Hypothesis Test .

\begin{tabular}{llcccc} 
Hypothesis & Beta & T-value & P-value & Action \\
\hline H1 & EB $\rightarrow$ CSAT & 0.300 & 13.76 & $* * *$ & Accepted \\
H2 & CSAT $\rightarrow$ BP & 0.755 & 5.48 & $* * *$ & Accepted \\
H3 & EB $\rightarrow$ BP & 0.884 & 3.89 & $* * *$ & Accepted
\end{tabular}

Note: EB-Electronic Banking, CSAT- customer satisfaction, BP - Bank performance

We again tested the effect of customer satisfaction on bank performance. CSAT $(\beta=0.755 ; t=5.48, p<0.000)$ and this led to the acceptance of hypothesis (H2). This suggested that customer satisfaction has greater effect on bank performance. The beta in the results shows that when customer satisfaction increases by $1 \%$ bank performance will increase by $75.50 \%$. Thus the more the customers of the bank are satisfied, the more they will patronize the services of the bank which will result in higher sales and subsequently profit for the bank. This is in line with the earlier findings of Bello and Dogarawa (2005). 
Lastly, the effect of E-banking on Bank performance was tested. BP $(\beta=0.884 ; \mathrm{t}=3.89$, $\mathrm{p}<0.000)$ and this led to the acceptance of hypothesis (H3). This suggested that the effect of E-banking has significant impact on Bank performance. Furthermore an increase in E-banking by $1 \%$ will lead to an increase of Bank performance by $88.40 \%$. Thus the more the banks introduces more innovative E-banking products and services, the more the bank will make a lot of profit. Thus the more the bank will introduce convenient, fast and easy going electronic banking services, the more the people will be happy and would want to pay more for the service. This is in line with the earlier studies of Migdadi (2013).

\section{Discussion:-}

This research has looked at a number of theoretical implications due to inadequate research works on E-banking in Djibouti. The purpose of this study is to investigate the outcome of E-banking on Bank performance. The outcome has proven a positive relationship between the two variables. The outcomes of the study revealed that when a bank invests more into electronic banking, customers of such banks become more satisfied, for that matter become more loyal to the bank. Customers becoming more loyal to the bank means they will patronize services of that bank only. This means there will be more sales for the bank which will finally result to profit making. This is in line with the study of Shamsuddoha and Alamgir (2010) on E-banking. The gap for this particular study is the fact that, most works that has been done focused on how employees and customers can improve bank performance in Djibouti neglecting the Electronic banking services.

Furthermore, the outcome of hypothesis (H1) revealed that there is a positive relationship between E-banking and customer satisfaction. The findings show that the more the bank introduces more of electronic banking services the more the customers will be satisfied. And they will be motivated to be loyal to the company. This is also supported by the works of Ishengoma (2011) and Ankit (2011).

Secondly, hypothesis $(\mathrm{H} 2)$ showed a positive relationship between customer satisfaction and bank performance. The findings depict that the more the customers are happy the more they will patronize the services of the bank. This is in line with the works of Yeung and Ennew (2000) and Mittal and Frennea (2010).

Lastly, hypothesis (H3), showed a positive relationship between E-banking and Bank performance. The findings depict that the more the bank introduces the E-banking services the more the company will make a lot of profit. This is in line with the works of Ongare (2013) and Deyoung, Lang and Nolle (2006).

\section{Contributions:}

This study contributes to literature and at the industry level in the area of E-banking and Bank performance. With regards to the industry level, the results of the study will help companies to invest more into Electronic banking so as to achieve the organizational objective, thus profit. The research also revealed that satisfying the customer leads the customer to be loyal to the bank. Which means they will spend more when given the opportunity on that bank. The study also revealed that the introduction of E-banking will motivate more customers to join the company because of the ease of use of the technology. Professionals, practitioners and other stakeholders must pay attention especially the researchers to E-banking from the developing country perspective.

\section{Conclusion:-}

This research work focused on E-banking and bank performance. The findings with regards to the E-banking and bank performance shows that when board of directors and management of banks take into consideration the happiness of their stakeholders like the customers, employees etc. by making the service of the bank very easy for them to access through the E-banking, they will begin to patronize more of the bank services and even go to the extent of recommending the banks to other customers. They will serve as an apostle of the bank preaching the good services of that bank.

Finally, the banks should find a way of making the electronic services easy to be use, easy to access and faster compared to the conventional system. This alone will yield positive performance in all aspect of the banking services. 


\section{References:-}

1. Abid H, and Noreen U. Ready to e-bank: An exploratory research on adoption of e-banking and e-readiness among customers and commercial banks in Pakistan. Spider, (2006). 31: 1-31.

2. Aghaei, M. R, Biglar, M .M, Jamshidian, A andAsadollahi, A. Investigating the effect of electronic Banking systems on customer satisfaction in Tehran, journal of Basic and applied scientific Research.(2013). issue 3, page 319- 324.

3. Ahmad, A.E.M. K. and Al-Zubi, H. A. E-banking Functionality and Outcomes of Customer Satisfaction: An Empirical Investigation ${ }^{e e}$ International Journal of Marketing Studies. (2011). 3(1): 50-65.

4. Aladawani, A. M. Online banking: A field study of drivers, development, challenges and expectations. International Journal of Information management (2001). 21: 213-225.

5. American Customer Satisfaction Index. Methodology report. Ann Arbor: University of Michigan. (2001).

6. Anderson, E.W and Fornell, C. A customer satisfaction research prospectus, in Rust, R.T. and Oliver, R.L. (Eds), Service Quality: New Directions in Theory and Practice, Sage, Thousand Oaks, (1994). pp. 241-268.

7. Ankit, S. Factors Influencing Online Banking Customer Satisfaction and Their Applied Psychology: London: Sage Publications Inc (2011).

8. Bello A. \& Dogarawa K. The impact of e-banking on customer satisfaction in Nigeria. Ahmed Bell University, Zaria-Nigeria, International Journal of Small Business Management, (2005). 40(1), 51-840.

9. Berger, A. N. The Economic Effects of Technological Progress: Evidence from the BankingIndustry. Journal of Money, Credit and Banking. (2003). Vol. 35No. 2, 141-76.

10. Chi, C.G. and Gursoy, D. Employee satisfaction, customer satisfaction and financial performance: an empirical examination", International Journal of Hospitality Management, (2009) Vol. 28 No. 2, pp. 245-253.

11. Chiou, J., S., \& Droge, C. Service quality, trust, specific asset investment, and expertise: Direct and indirect effects in a satisfaction-loyalty framework. Journal of the Academy of Marketing Science. (2006). 34(4), 613627.

12. Claessens S, Glaessner T, and Klingebiel D.E-finance in emerging markets: Is leapfrogging possible? Financial Markets, Institutions \& Instruments. (2000). 11: 1-125.

13. Daniel, E. Provision of electronic banking in the UK and the Republic of Ireland. International Journal of Bank marketing. (1999).17: 72-83.

14. DeYoung, R., Lang, W. W. and Nolle, D. E. How the Internet Affects Output and Performance at Community Banks, Journal of Banking and Finance. Journal of Small Business Management, (2006). 4(2), 51-840.

15. Dossi, A and Patelli, L. You learn from what you measure: Financial and non-financial performance measures in multinational companies. Long Range Planning. (2010). 43(4), 498-526.

16. Fornell, C. A. National customer satisfaction barometer: The Swedish experience. Journal of Marketing, (1992). 56(1), 6-21.

17. Fornell, C., Johnson, M. D., Anderson, E. W., Cha, J., and Everitt Bryant, B. The American customer satisfaction index: Nature, purpose, and findings. Journal of Marketing. (1996). 60(4), 7-18.

18. Fornell, C., and Larcker, D. F. Evaluating structural equation models with unobservable variables and measurement error. Journal of Marketing Research. (1981a). 18(1), 39-50.

19. Fornell, C., and Larcker, D. F. Evaluating structural equation models with unobservable variables and measurement error. Journal of Marketing Research. (1981b). 18(1), 39-50.

20. Guo, C., Kumar, A., and Jiraporn, P. Customer satisfaction and profitability: Is there a lagged effect? Journal of Strategic Marketing. (2004). 2, 129-144.

21. Hair Jr, J. F., Hult, G. T. M., Ringle, C., and Sarstedt, M. A primer on partial least squares structural equation modeling (PLS-SEM). Sage publications. (2016).

22. Hair, J., Ringle, C. M. and Sarstedt, M. PLS-SEM: Indeed a Silver Bullet. Journal of Marketing Theory and Practice. (2011). 19(2), 139-151.

23. Hallowell, R. The relationships of customer satisfaction, customer loyalty and profitability: an empirical study, International Journal of Service Industry Management. (1996). Vol. 7 No. 4, pp. 27-42.

24. Han, S. and Baek, S. Antecedents and Consequences of Service Quality in Online Banking: An Application of the SERVQUAL Instrument. Advances in Consumer Research. (2004). 31, 208-214.

25. Hansemark, O. C, Albinson, M. Customer Satisfaction and Retention: The experiences of Individual Employees. Managing Service Quality. (2004).14: 40-57.

26. Hasan, I, Maccario, A. and Zazzara, C. Do Internet Activities Add Value? The Italian Bank Experience, Working Paper, Berkley Research Center, New York University. (2002).

27. Hernando, I. and Nieto, M. J. Is the Internet Delivery Channel Changing Banks' Performance? The Case of Spanish Banks, Banco de Espana, Unpublished Manuscript. (2005). 
28. Heskett, J.L., Jones, T.O., Loveman, G.W., Sasser, W.E. and Schlesinger, L.A. "Putting the service-profit chain to work", Harvard Business Review. (1994). Vol. 72 No. 2, pp. 164-174.

29. Hoq, M. Z. and Amin, M. The Role of Customer Satisfaction to enhance Customer Loyalty. African Journal of Business Management. (2010). Vol. 4, No. 12, pp. 2385-2392.

30. Ishengoma A. I. Analysis of mobile-banking for financial inclusion in Tanzania: Case of Kibaha District Council Kibaha, Tanzania. (2011).

31. Kanning, U. P. and N. Bergmann, N. Predictors of Customer Satisfaction: Testing the classical paradigms. Managing Service Quality. An International Journal. (2009). Vol.19, No. 4, pp. 377-390.

32. Kotler, P. Marketing management (6th edn.), Longitudinal Assessment of customer, Prentice-Hall LaBarbera, New Jersey. (2000).

33. Kumbhar, VM. Factors affecting customer satisfaction: Some evidence from Indian banks. Romania Knowledge Management Research \& Practice. (2011).3:1-14.

34. Magemhe S, and Shemi, A.P. Challenges and opportunities for adapting electronic commerce in developing country: The Botswana perspective. IAABD Conference proceedings, Port Elizabeth. (2002).

35. Malhotra, $\mathrm{P}$ and Singh B. Current state of internet banking in India and its implication for the Indian Banking Industry. Eurasian Journal of Business and Economics. (2007). 2(4), 43 - 62.

36. Messick, S. Validity. In R. L. Linn (Ed.), Educational Measurement (3rd ed.). New York, NY.: Macmillan. (1988).

37. Migdadi, Y. K. The Quality of internet banking services encounter in Jordan. Journal of Internet Banking and Commerce. (2013). 13(3), 1-8.

38. Mishra, R. K and Kiranamai J E-banking: A case of India. ICFAI Journal of publication Administration. (2009). 5: 55-65.

39. Mittal, V. and Frennea, C. Customer satisfaction: A strategic review and guideline for managers. MSI Fast Forward Series. Cambridge, MA: Marketing Science Institute. (2010).

40. [. Mobarek, A. E-Banking Practices and Customer Satisfaction: A Case Study in Botswana. In 20th Australasian Finance \& Banking Conference. (2007).

41. Munari, L., Ielasi, F., \& L. Bajetta, L. Customer Satisfaction Management in Italian Banks', Qualitative Research in Financial Markets. (2013). Vol. 5, No. 2, pp. 139-160.

42. Oliver RL Satisfaction: A Behavioral Perspective on the Consumer. McGraw Hill, New York. (1997).

43. Ongare, H, O. The effect of electronic banking on the financial performance of commercial banks in Kenya, Unpublished MBA Thesis University of Nairobi. (2013).

44. Oginni, S. O., Mohammed, A., El-maude, J. G. A., Abam, I. E-banking and Bank Performance: Evidence from Nigeria, International Journal of Scientific Engineering and Technology, (2013). Volume No.2, Issue No.8, pp: 766-771.

45. Polatogler, V. N. and Ekin, S. An empirical investigation of the Turkish consumers acceptance of internet banking services. International Journal of Bank Marketing. (2001). 19(4), 156-165.

46. ]. Ringle, C., M, Wende, S., \& Becker, J., M., (Producer). SmartPLS 3. Retrieved from http://www.smartpls.com.(2015).

47. Rust, R.T, Zahorik, A.J, and Keiningham, T.L. Return on quality (ROQ): making service quality financially accountable, Journal of Marketing. (1995). Vol. 59 No. 2, pp. 58-70.

48. Schneider, B. and Bowen, D.E. Winning the Service Game, HBS Press, Boston, MA. (1995).

49. Shamsuddoha, M, and Tasnuba, A. Determinants of Customer Relationship Management, Washington, DC: Sage Publications Inc. (2011).

50. Sumra, S. H, Manzoor, M. K, Sumra, H. H, and Abbas, M. The Impact of E-Banking on the Profitability of Banks: A Study of Pakistani Banks. Journal of Public Administration and Governance. (2011).

51. Sweeney, J. and Swait, J. The effects of brand credibility on customer loyalty, Journal of Retailing and Consumer Services, (2008). Vol. 15 No. 3, pp. 179-193.

52. Terpstra, M., Killen, T and Sijtsma, K. How to develop a Customer Satisfaction Scale with Optimal Construct Validity, Quality andQuantity. (2014). Vol. 48, No. 5, pp. 2719-2737

53. Woldie, A., Hinson, R., Iddrisu, H. and Boateng, R. Internet banking: an initial look at Ghanaian bank consumer. Banks and Bank Systems. (2008). 3(3):35-46.

54. Wallis Report. The Financial System Inquiry Final Report (Chairman: Mr. Stan Wallis), AGPS, Canberra. (1997).

55. Yeung, M., and Ennew, C. From customer satisfaction to profitability. Journal of Strategic Marketing. (2000). 8, 313-326. 